\title{
INVESTIGATION OF THE SHEAR STRENGTH AND BEARING CAPACITY OF CONTAMINATED SANDY SOIL BY OIL PRODUCTS
}

Helmy, H. M. ${ }^{(1)}$;Farid, M. N. ${ }^{(2)}$ and Abdel Mouty, Asmaa. S.

1) Department of Structural Engineering, Faculty of Engineering, Ain Shams University. 2) Department of Environmental Engineering Science, Environmental Institute, Ain Shams University.

\begin{abstract}
Oil stations may pose numerous risks to the environment. The main environmental risk is associated with the potential leakage from underground oil tanks, which may endanger the soil and/or groundwater. Consequently, geotechnical and environmental problems may arise. In this paper, the influence of soil contamination by oil products on the shear strength and bearing capacity of particularly sandy soil has been investigated and analyzed. An extensive experimental study has been conducted to evaluate the potential impacts of contaminating the sand with different oil products in a variety of contamination content. The obtained results showed that the contaminated sand may provide quite small apparent cohesion strength that slightly increases by increasing the oil viscosity. Also, the angle of shearing resistance was found remarkably decreases by increasing both the contaminating oil content and viscosity.

Moreover, the bearing capacity of the contaminated sand has been predicted. Considerable reduction in the bearing capacity of shallow foundations rested on contaminated sand was revealed.
\end{abstract}

Keywords: contamination; oil products; shear strength; bearing capacity.

\section{INTRODUCTION}

Thought the surrounding area to a petroleum stations, a wide range of challengers regarding the human health and safety may be encountered. Petroleum stations may pose numerous risks to the environment. The main 
environmental risk is considerably associated with the potential release of the petroleum station sources, which may endanger the air, soil and /or groundwater. It is well-recognized all over the world that oil spills from petroleum stations invariably occur, resulting in contaminating the inherent sub soils in the surrounding area. Soil contamination by oil spills from petroleum stations may be attributed to several sources, such as leakage of oil from, in essence, underground storage tanks and supplying pipe line due to ineffective joints or structural damage (Beier et al., 2007), (David, 1993). The presence of oil spills within the soil formation may significantly influence the inherent soil characteristics. Any change in engineering properties and behavior of the soil strata may lead to loss of bearing capacity, an increase in total or differential settlements of the foundation systems of the structures. Consequently, structures may undergo functional or structural failure (Fine et al., 1997).

Moreover, the continual inflow of the oil into the soil may results in a pollution of the existing groundwater. Recognizing that both soil and groundwater are considered of the basic elements of the environment, thus it can consequently be highlighted that leakage of oil from petroleum stations usually yields to both geotechnical and environmental problems (El-Sayed, 2009), (Rajab et al., 2016) Therefore, the investigation of the sources, relative impacts and solutions of the soil contamination by oil from petroleum stations has become one of the urgent topics in the geotechnical and environmental engineering. It is worth mentioning that the influence of contaminating oil may vary according to a number of aspects, such as soil type, oil type, oil 
viscosity, the temperature, among others (Ahmed et al, 2009), (Shin et al, 1999).

The main objective of this paper is to investigate the influence of soil contamination by oil products on the soil shear strength and bearing capacity. The present study focuses particularly on sandy soil, as being one of the common soil formations in Egypt. In this regard, an extensive experimental study has been conducted to evaluate the potential impacts of contaminating the sand with oil products. Different oil products has been used in a variety of contamination content. The basic geotechnical characteristics of the original sand has been determined in the laboratory The shear strength parameters of both the original and the contaminated sand have been ascertained in the laboratory by series of direct shear box tests. Moreover, the bearing capacity of the contaminated sand has been predicted. This is in order to assess the influence of soil contamination on one of the vital soil engineering parameters.

\section{EXPERIMENTAL STUDY}

A laboratory testing program has been conducted at the Soil Mechanics Laboratory in Ain Shams University in Egypt. The testing program comprised tests to determine both physical and mechanical properties of the tested materials, i.e. original sand, oil products and contaminated sand.

\section{TESTED MATERIALS}

The current experimental study has been conducted on nature siliciuos sand. The tested sand was extraced from natural ground at certain project located in New Cairo in Egypt. The predominant index properties of the 
original sand have been determianed. According to the grading curve shown in Figure (1), the sand is poorly graded, course to medium, with some fine to medium gravel and with traces of fines. The precents of gravel, sand and fines are $15.0 \%, 82.50 \%$ and $2.5 \%$, respectively. Furthermore, the minimum and maximum void ratios of the original sand have been determined in the laboratory. The corrsponding maximum and minimum dry densities of the original sand were $1.996 \mathrm{kN} / \mathrm{m} 3$ and $1.662 \mathrm{kN} / \mathrm{m} 3$, respectively. The laboratory specific gravity of original sand was about 2.657. Table (1) provides a summary of the index properties of the sand. Compaction Test, i.e. modified Proctor test, has been carreied out on the original sand. The obtanined compaction curve is demonstrated in Figure (2).

Table(1): The index properties of the used sand

\begin{tabular}{|c|c|c|c|c|c|}
\hline D10 & D30 & D60 & Cu & Cc & Gs \\
\hline \hline 0.292 & 0.5833 & 1.2519 & 4.2876 & 0.9308 & 2.657 \\
\hline
\end{tabular}

Three different sorts of oil have been employed, representing different oil products in the Egyptian society, i.e. solar, diesel engine oil and gears oil. The fundamental difference between these oil products is the degree of viscosity. Therefore, physical laboratory tests have been carried out to determine the kinematic viscosity of each oil product, as shown in Table (2). The values of kinematic viscosities were 37, 200 and 460 centistokes for the used three oil products solar, diesel engine oil and oil of gears, respectively. 
Table(2): Kinematic viscosities of the used oil products

\begin{tabular}{|c|c|}
\hline Physical Properties of oils & $\begin{array}{c}\text { Kinematic Viscosity } \\
\text { (centistokes) }(\mathrm{mm} 2 / \mathrm{sec})\end{array}$ \\
\hline used oil & $\operatorname{At30}^{\circ} \mathrm{C}-40^{\circ} \mathrm{C}$ \\
\hline Type (1): Solar & 37 \\
\hline Type (2): Diesel Engine Oil & 200 \\
\hline Type (3): Gears Oil & 460 \\
\hline
\end{tabular}

\section{Sand-Oil Mixture:}

For each oil type, the tested samples were prepared by mixing clean sand with three different oil percentages by weight of the dry sand; $2 \%, 5 \%$ and $10 \%$. To achieve the required relative density, the samples were placed and compacted. Sand was tested for three different relative densities; $20 \%, 50 \%$ and $80 \%$. Table (3) shows densities of sand samples that used to access the required values of relative densities.

Table(3): Densities of sand samples

\begin{tabular}{|c|c|c|c|}
\hline Dr & e & $\gamma(\mathbf{g m} / \mathbf{c m 3})$ & \% compaction \\
\hline 0.2 & 0.545 & 1.719 & $86.12 \%$ \\
\hline 0.5 & 0.456 & 1.814 & $90.88 \%$ \\
\hline 0.8 & 0.384 & 1.919 & $96.14 \%$ \\
\hline
\end{tabular}

\section{Shear Strength:}

Direct shear test by tested a number of dry samples of soil each under a different vertical force. Direct shear tests were performed with different applied normal stresses $(0.5,1.00$ and $2.00 \mathrm{~kg} / \mathrm{cm} 2)$ and the shearing resistance at peak state was obtained for each normal stress. The value of shear strength parameters were then obtained from the best line fitting the plotted points. 
J. Environ. Sci.

Institute of Environmental Studies and Research - Ain Shams University

\section{RESULTS AND DISCUSSION}

1 Effect of oil content on shear strength parameters: It has been revealed, in general as illustrated in table (4), that the cohesion intercept slightly increases with the increase of oil content. Nevertheless, the results shown in Figures (4),(6) and (8) indicate that quite small values of the cohesion strength have been encountered such that the acquired values of the cohesion intercept were found ranging between 3.9 and $14.1 \mathrm{kPa}$. In accordance, it has been assumed in the present study that the cohesion parameter has insignificant impact on the shear strength of the tested soils. It has been, therefore, decided to account for only the influence of the angle of shear resistance that tends to decrease with the increase in oil content as shown in figures (3), (5) and (7).

The results showed that, In case of loose conditions (at Dr=20\%), as the oil percentage increases from $2 \%$ to $10 \%$, the reduction of the angle of shearing resistance ( () is about $(23-44 \%)$ with type (1), about $(41-52 \%)$ with type (2), and about (44 - 57\%) with type (3). Whereas, at $\mathrm{Dr}=50 \%$, as the oil percentage increases from $2 \%$ to $10 \%$ the reduction of the angle of shearing resistance ( () is about $(34-45 \%)$ with type (1), about $(38-51 \%)$ with type (2), and about (42-55\%) with type (3). At dense conditions (at $\operatorname{Dr}=80 \%$ ), as the oil percentage increases from $2 \%$ to $10 \%$, the reduction of the angle of shearing resistance $(\emptyset)$ is about (32 - 42\%) with type (1), about (36-50\%) with type (2), and about (41 - 53\%) with type (3). 
Table(4): Effect of oil content on shear strength parameters

\begin{tabular}{|c|c|c|c|c|c|c|c|c|c|c|}
\hline \multirow{3}{*}{$\begin{array}{c}\text { Oil } \\
\text { type }\end{array}$} & \multirow{3}{*}{$\begin{array}{l}\text { Dr } \\
(\%)\end{array}$} & \multirow{3}{*}{$\begin{array}{c}\mathrm{Y} \\
(\mathrm{gm} / \mathrm{cm} 3)\end{array}$} & \multicolumn{8}{|c|}{ Oil percentage (\%) } \\
\hline & & & \multicolumn{2}{|c|}{$\begin{array}{c}\text { Raw } \\
\text { material }(0 \%)\end{array}$} & \multicolumn{2}{|c|}{$2 \%$} & \multicolumn{2}{|c|}{$5 \%$} & \multicolumn{2}{|c|}{$10 \%$} \\
\hline & & & $\begin{array}{c}\mathrm{C} \\
(\mathrm{kPa})\end{array}$ & $\boldsymbol{\omega}\left({ }^{\circ}\right)$ & $\begin{array}{c}\mathrm{C} \\
(\mathbf{k P a})\end{array}$ & $\begin{array}{c}\mathbf{0} \\
\left({ }^{\mathbf{0}}\right)\end{array}$ & $\begin{array}{c}\mathrm{C} \\
(\mathrm{kPa})\end{array}$ & $\begin{array}{c}\boldsymbol{(} \\
\left({ }^{\mathbf{o}}\right)\end{array}$ & $\begin{array}{c}\mathrm{C} \\
(\mathbf{k P a})\end{array}$ & $\begin{array}{c}\mathbf{0} \\
\left({ }^{(0)}\right)\end{array}$ \\
\hline \multirow{3}{*}{$\begin{array}{l}\text { Type } \\
\text { (1) }\end{array}$} & 20 & 1.719 & 0 & 35.2 & 3.9 & 23.7 & 6 & 22.3 & 8.1 & 19.5 \\
\hline & 50 & 1.814 & 0 & 37.2 & 4.9 & 24.2 & 7.4 & 23.2 & 9.0 & 20.1 \\
\hline & 80 & 1.919 & 0 & 39.8 & 6 & 26.7 & 8.1 & 24.2 & 9.5 & 22.7 \\
\hline \multirow{3}{*}{$\begin{array}{c}\text { Type } \\
\text { (2) }\end{array}$} & 20 & 1.719 & 0 & 35.2 & 4.2 & 20.6 & 6.8 & 18.4 & 8.8 & 16.6 \\
\hline & 50 & 1.814 & 0 & 37.2 & 6.7 & 23 & 8.8 & 20.7 & 11.0 & 18.4 \\
\hline & 80 & 1.919 & 0 & 39.8 & 8.6 & 25.1 & 12 & 21.4 & 13.5 & 19.8 \\
\hline \multirow{3}{*}{$\begin{array}{l}\text { Type } \\
\text { (3) }\end{array}$} & 20 & 1.719 & 0 & 35.2 & 4.8 & 19.6 & 7.4 & 17.2 & 10.3 & 15.0 \\
\hline & 50 & 1.814 & 0 & 37.2 & 8.8 & 21.8 & 10.3 & 18.6 & 12.3 & 16.6 \\
\hline & 80 & 1.919 & 0 & 39.8 & 11.3 & 22.8 & 13.9 & 19.7 & 14.1 & 18.6 \\
\hline
\end{tabular}

2 Effect of viscosity on the shear strength parameters: By increasing the viscosity of oil in sand-oil mixes, the angle of shearing resistance tends to decrease as shown in figures (9), (10) and (11), where, The values of the angle of shear resistance are reduced at rates ranging about (35\%) at Oil percentage $(2 \%),(44 \%)$ at Oil percentage $(5 \%)$ and $(47 \%)$ at Oil percentage $(10 \%)$.

\section{Bearing Capacity:}

The bearing capacity of shallow foundations may be affected by sand contamination. This effect has been investigated by calculating the bearing capacity for contaminated sand. The bearing capacity has been calculated using the codified equation in the Egyptian Code of Practice shown below (equation 1).

qult $=\mathrm{C} \mathrm{Nc} \lambda \mathrm{c}+\gamma \mathbf{1} \mathrm{Df} \mathrm{Nq} \lambda \mathrm{q}+\gamma \mathbf{2} \mathrm{B} \mathbf{N} \gamma \gamma$ 
The bearing capacity has been predicted for an isolated square footing with assumed dimensions $2 \times 2$. The foundation soil has been considered as contaminated sand at $2 \%, 5 \%$ and $10 \%$ oil percentage and with a variety of relative densities. The foundation depth, Df , has been assumed $1.50 \mathrm{~m}$. Both effective soil densities, $\gamma 1$ and $\gamma 2$, above and below the foundation level, respectively, have been taken as a constant value of $18 \mathrm{KN} / \mathrm{m} 3$.

The results showed that, by increasing the viscosity of oil in the sand-oil mixes, the ultimate bearing capacity generally decrease as illustrated in table (5). In accordance, by generally increasing the oil viscosity from 37 to 460 centistokes and at an oil percentage of $2 \%$, the reduction in the ultimate bearing capacity has been found ranging from $71 \%$ to $77 \%, 78 \%$ to $79 \%$ and $80 \%$ to $82 \%$, at relative densities, $\mathrm{Dr}$, of 20,50 and $80 \%$, respectively. Whereas, at an oil percentage of $5 \%$, the reduction in the ultimate bearing capacity has been found ranging from $72 \%$ to $81 \%, 80 \%$ to $83 \%$ and $82 \%$ to $85 \%$, at relative densities, $\mathrm{Dr}$, of 20,50 and $80 \%$, respectively. At the maximum examined oil percentage of $10 \%$, the reduction in the ultimate bearing capacity has been found ranging from $77 \%$ to $83 \%, 81 \%$ to $85 \%$ and $83 \%$ to $86 \%$, at relative densities, Dr, of 20,50 and $80 \%$, respectively. The detailed results are demonstrated in Figures (12) through (14). 
Table(5): Variation of ultimate bearing capacity with different oil percentage

\begin{tabular}{|c|c|c|c|c|c|}
\hline \multirow{2}{*}{$\begin{array}{c}\text { Relative } \\
\text { density }\end{array}$} & \multirow{2}{*}{ Oil type } & \multicolumn{4}{|c|}{ qult (kN/m2) } \\
\cline { 2 - 6 } & & At 0\% & At 2\% & At 5\% & At 10\% \\
\hline \multirow{3}{*}{20} & 1 & 1785 & 514 & 490 & 410 \\
\cline { 2 - 6 } & 2 & 1785 & 377 & 349 & 326 \\
\cline { 2 - 6 } & 3 & 1785 & 352 & 321 & 305 \\
\hline \multirow{3}{*}{50} & 1 & 2367 & 568 & 571 & 452 \\
\cline { 2 - 6 } & 2 & 2367 & 543 & 474 & 421 \\
\cline { 2 - 6 } & 3 & 2367 & 526 & 416 & 381 \\
\hline \multirow{3}{*}{80} & 1 & 3477 & 780 & 650 & 591 \\
\cline { 2 - 6 } & 2 & 3477 & 726 & 574 & 525 \\
\cline { 2 - 6 } & 3 & 3477 & 638 & 528 & 483 \\
\hline
\end{tabular}

\section{CONCLUSIONS}

An extensive laboratory testing program was carried out to investigate the effect of oil contamination on the properties of sandy soil. The amount of up to 10 percent by weight of dry soil samples selected as oil contamination. Moreover, the ultimate bearing capacity of contaminated sand was predicted for an isolated footing $2 \times 2 \mathrm{~m}$. On bases of the results of this research, the following conclusions can be provided:

1. When the oil content increases from zero to about $10 \%$, the friction angle decreases by about (32-53\%) for relative densities (20\%, $50 \%$ and $80 \%)$.

2. For oil contaminated sandy soil with viscosity 37 centistokes, as the oil percentage increases from $2 \%$ to $10 \%$, the reduction of the angle of shearing resistance $(\varphi)$ is about $(23-44 \%),(34-45 \%)$ and $(32-42 \%)$ for Relative densities $20 \%, 50 \%$ and $80 \%$ respectively.

3. For oil contaminated sandy soil with viscosity 200 centistokes, as the oil percentage increases from $2 \%$ to $10 \%$, the reduction of the angle of 
shearing resistance $(\varphi)$ is about $(41-52 \%),(38-51 \%)$ and $(36-50 \%)$ for Relative densities $20 \%, 50 \%$ and $80 \%$ respectively.

4. For oil contaminated sandy soil with viscosity 460 centistokes, as the oil percentage increases from $2 \%$ to $10 \%$, the reduction of the angle of shearing resistance $(\oplus)$ is about (44-57\%), (42-55\%) and (41-53\%) for Relative densities $20 \%, 50 \%$ and $80 \%$ respectively.

5. Consequent to the decrease in the soil friction angle upon the oil contamination, the ultimate bearing capacity remarkably decreases. When the oil content increases up to about $10 \%$, the ultimate bearing capacity is reduced by about (71\%-86\%) for relative densities $(20 \%, 50 \%$ and $80 \%)$.

6. For Relative density $20 \%$; by generally increasing the oil viscosity from 37 to 460 centistokes, the reduction in the ultimate bearing capacity has been found ranging from ( $71 \%$ to $77 \%),(72 \%$ to $81 \%),(77 \%$ to $83 \%)$ at oil percentage $2 \%, 5 \%$ and $10 \%$ respectively.

7. For Relative density 50\%; by generally increasing the oil viscosity from 37 to 460 centistokes, the reduction in the ultimate bearing capacity has been found ranging from $(78 \%$ to $79 \%),(80 \%$ to $83 \%),(81 \%$ to $85 \%)$ at oil percentage $2 \%, 5 \%$ and $10 \%$ respectively.

8. For Relative density $80 \%$; by generally increasing the oil viscosity from 37 to 460 centistokes, the reduction in the ultimate bearing capacity has been found ranging from $80 \%$ to $82 \%, 82 \%$ to $85 \%, 83 \%$ to $86 \%$, at oil percentage $2 \%, 5 \%$ and $10 \%$ respectively. 
Helmy, et al

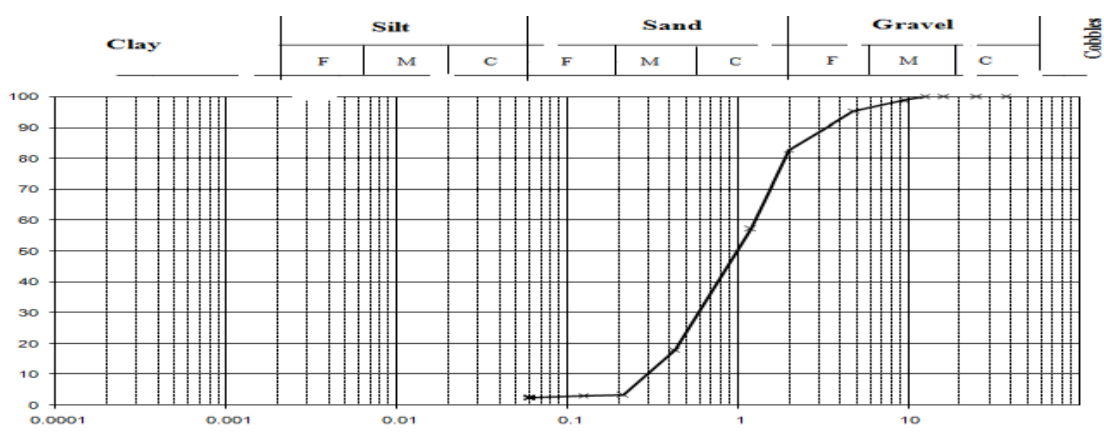

Figure (1): Grain size distribution curve for original sand

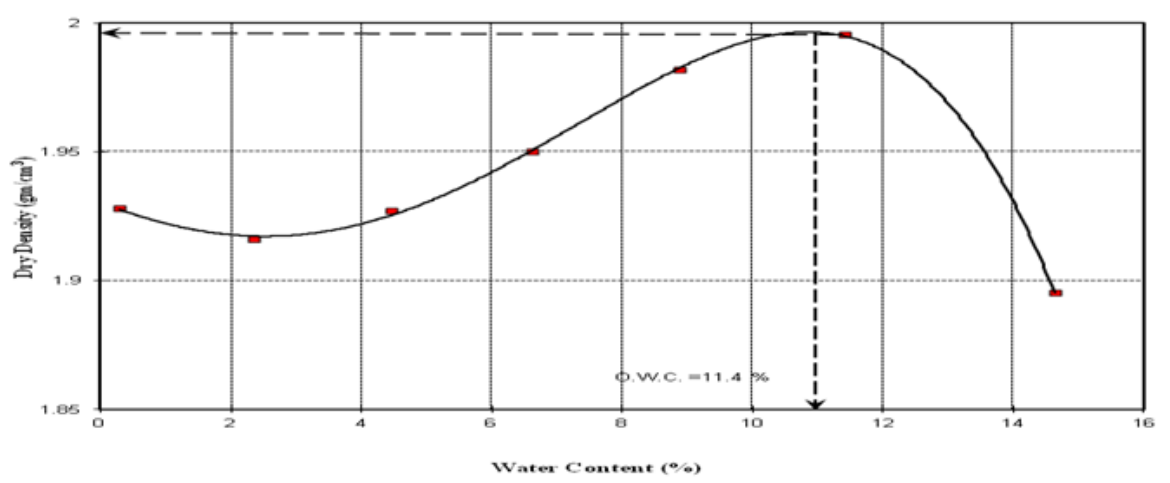

Figure (2): Compaction curve for original sand

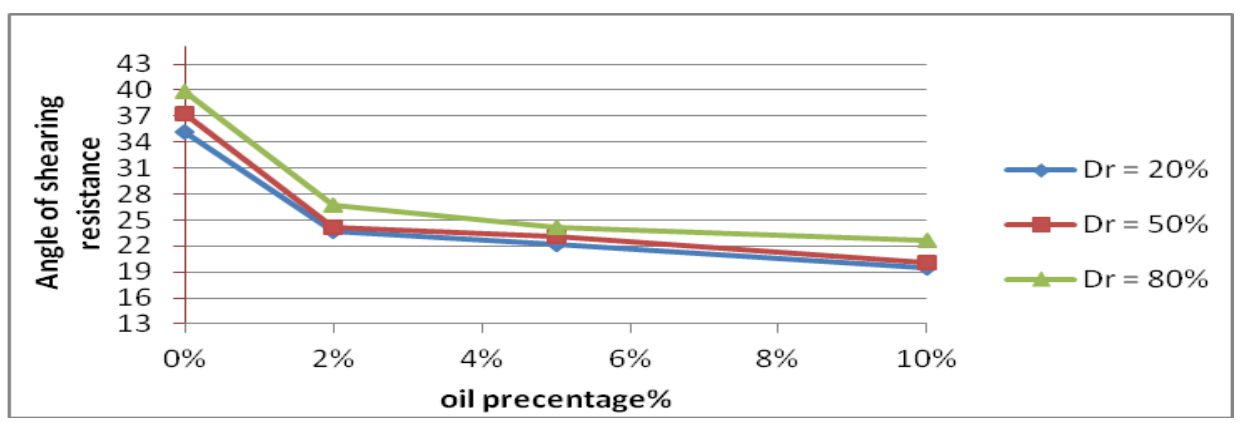

Figure (3): Relationship between oil contamination percentage and angle of shearing resistance of sand for oil type 1 (solar). 
J. Environ. Sci.

Institute of Environmental Studies and Research - Ain Shams University

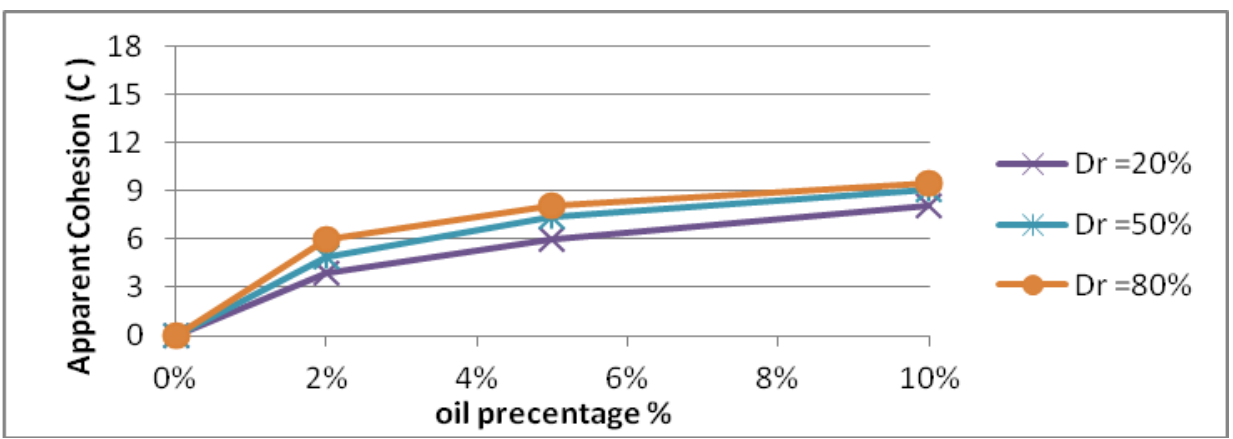

Figure(4): Relationship between oil contamination percentage and apparent cohesion of sand for oil type 1 (solar).

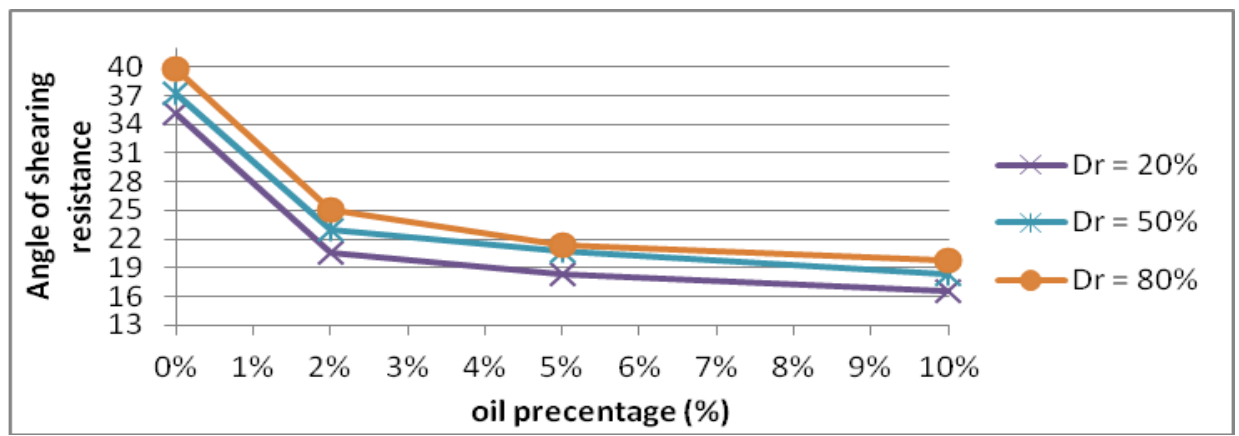

Figure(5): Relationship between oil contamination percentage and angle of shearing resistance of sand for oil type 2 (diesel engine oil)

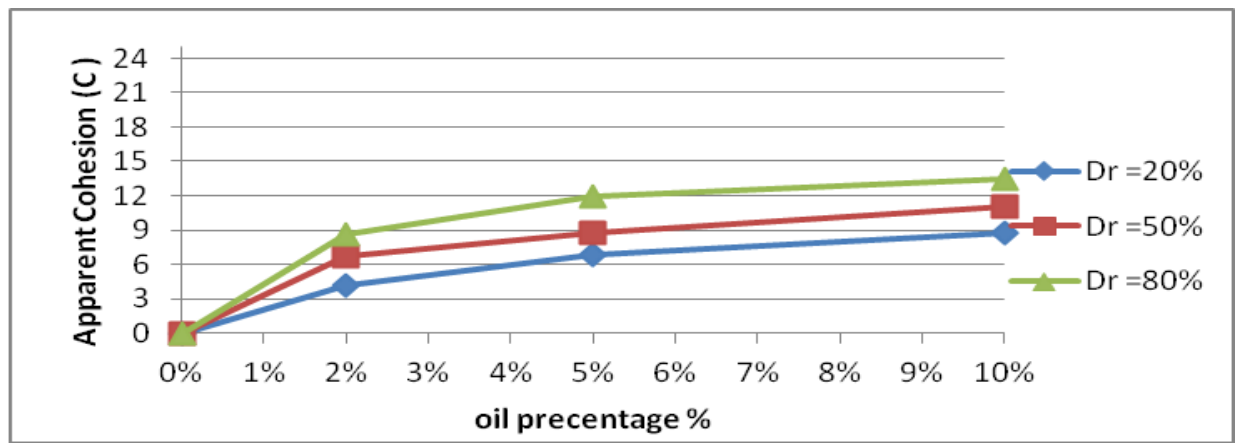

Figure (6): Relationship between oil contamination percentage and apparent cohesion of sand for oil type 2 (diesel engine oil) 
Helmy, et al

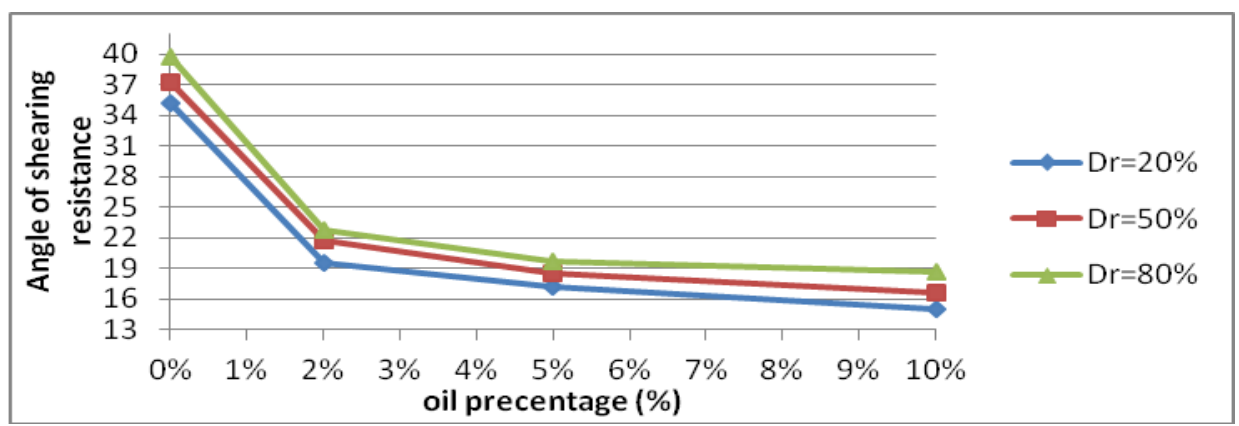

Figure(7): Relationship between oil contamination percentage and angle of shearing resistance of sand for oil type 3 (gears oil)

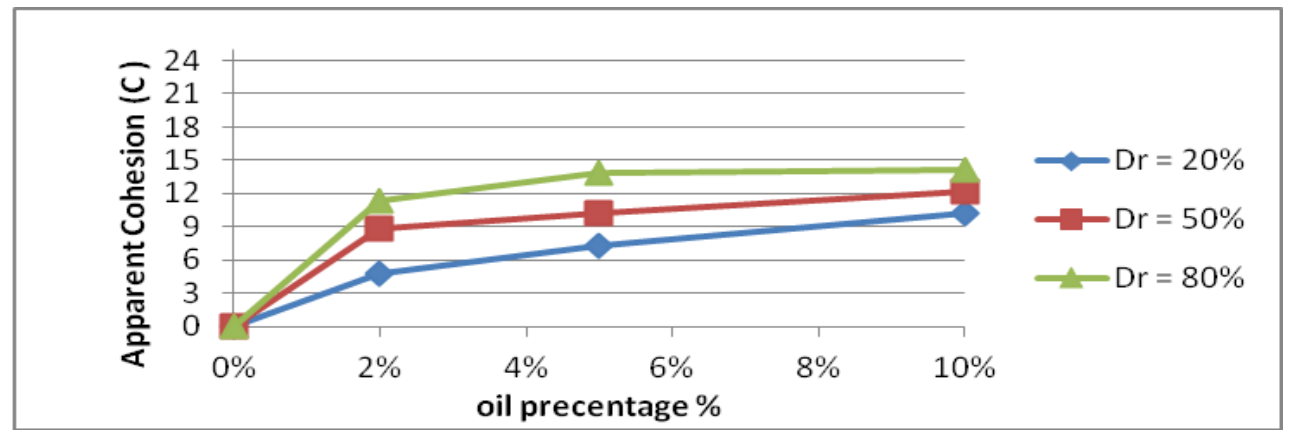

Figure(8): Relationship between oil contamination percentage and apparent cohesion of sand for oil type 3 (gears oil)

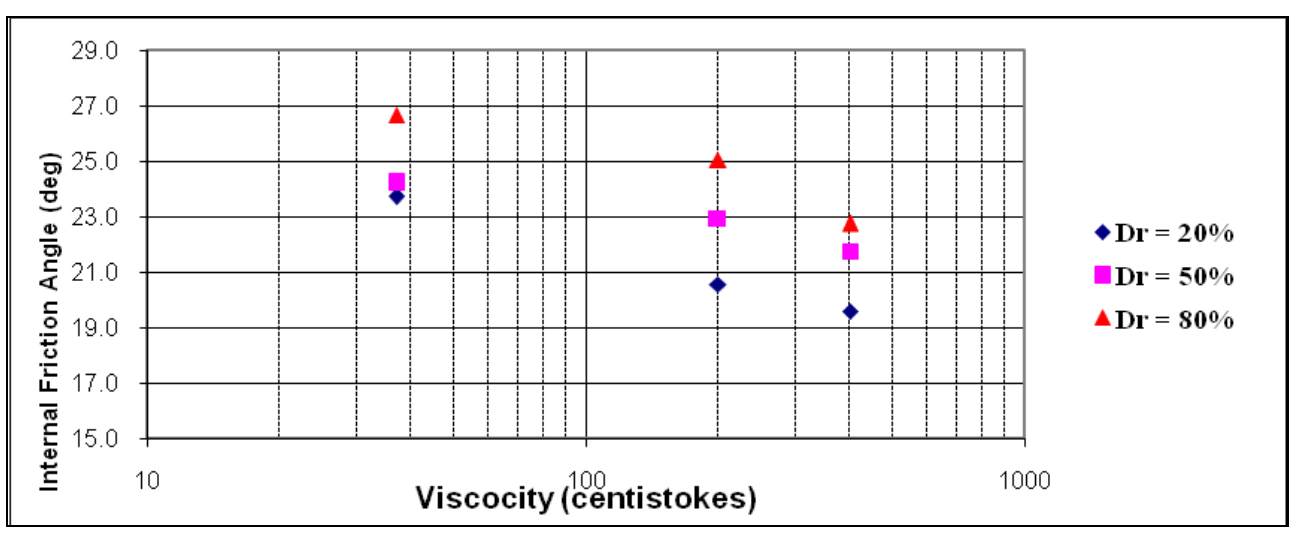

Figure(9): Relationship between oil viscosity and angel of shearing resistance at $2 \%$ oil content. 
J. Environ. Sci.

Institute of Environmental Studies and Research - Ain Shams University

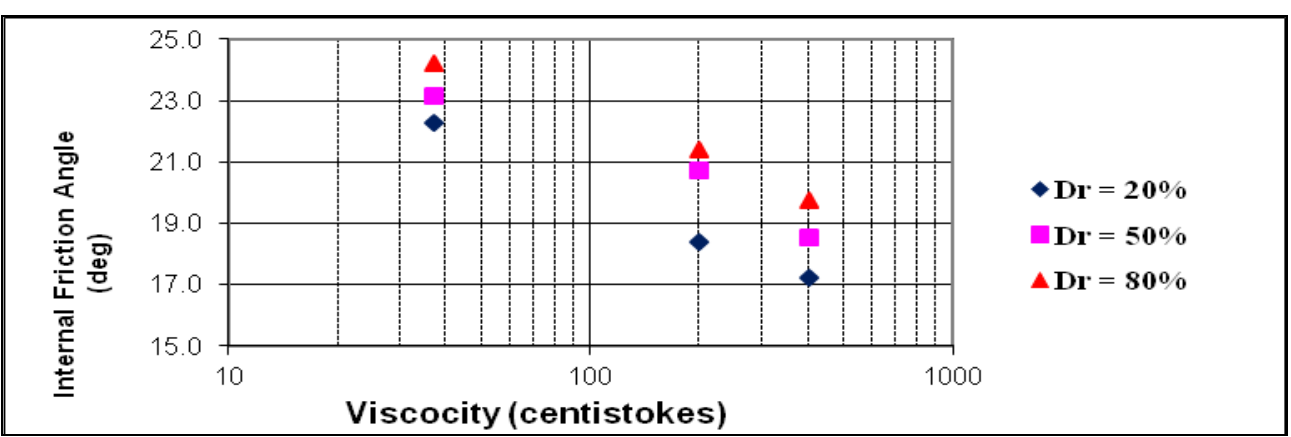

Figure(10): Relationship between oil viscosity and angel of shearing resistance at $5 \%$ oil content.

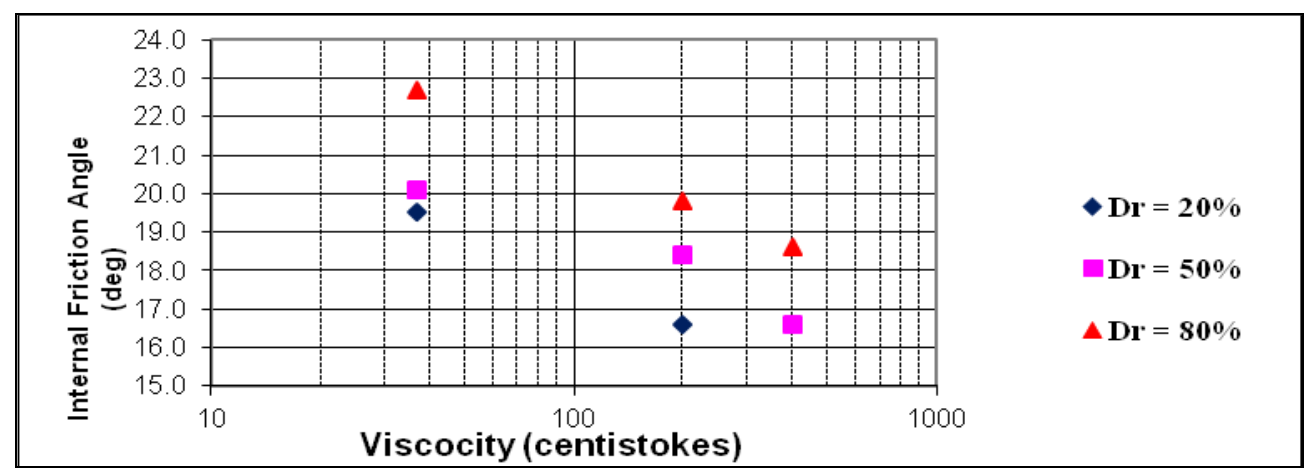

Figure(11): Relationship between oil viscosity and angel of shearing resistance at $10 \%$ oil content.

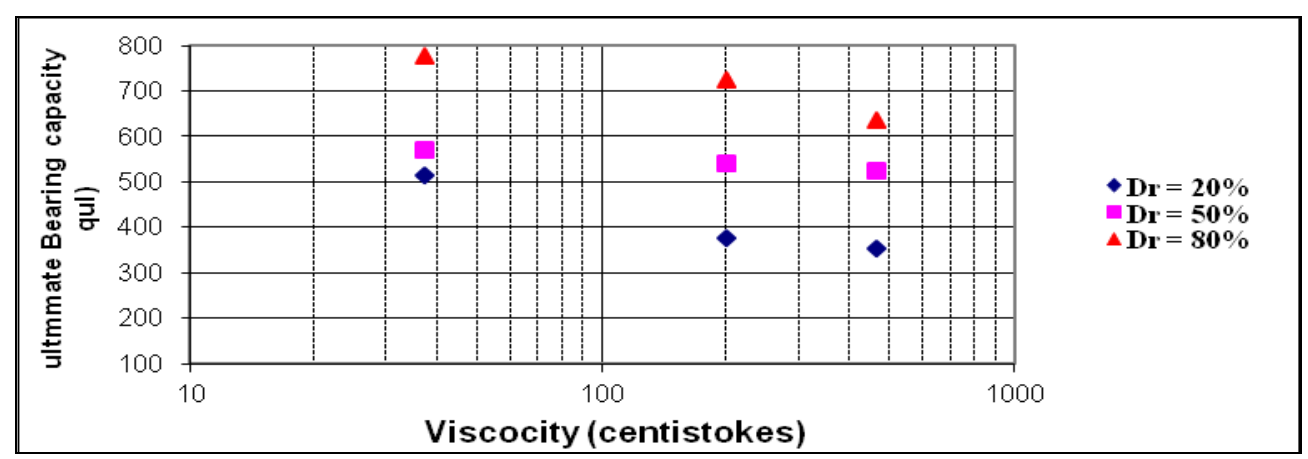

Figure(12): Relationship between oil viscosity and ultimate bearing capacity at $2 \%$ oil content. 


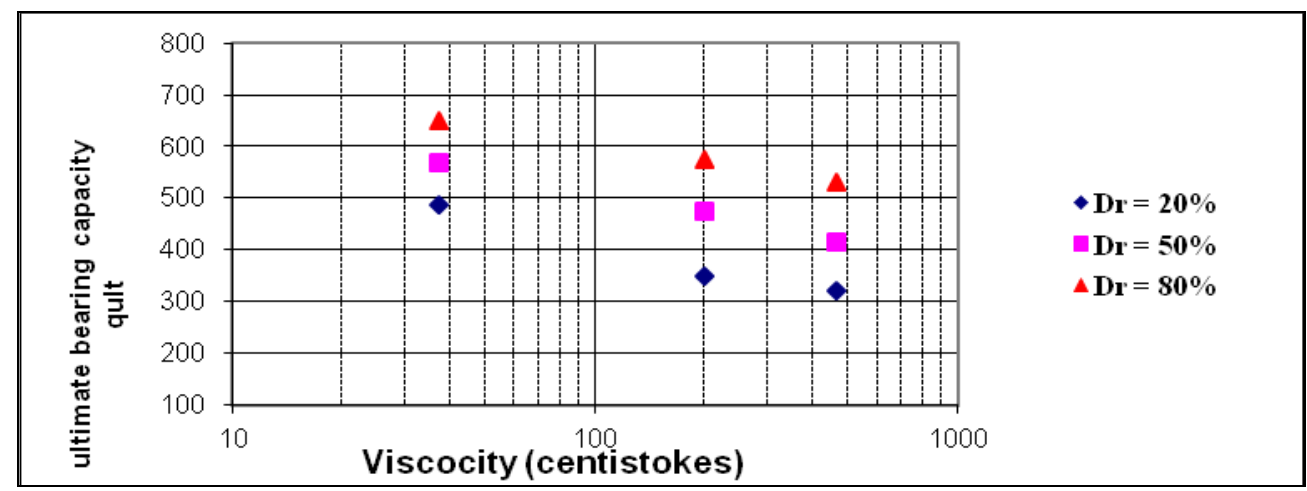

Figure(13): Relationship between oil viscosity and ultimate bearing capacity at $5 \%$ oil content.

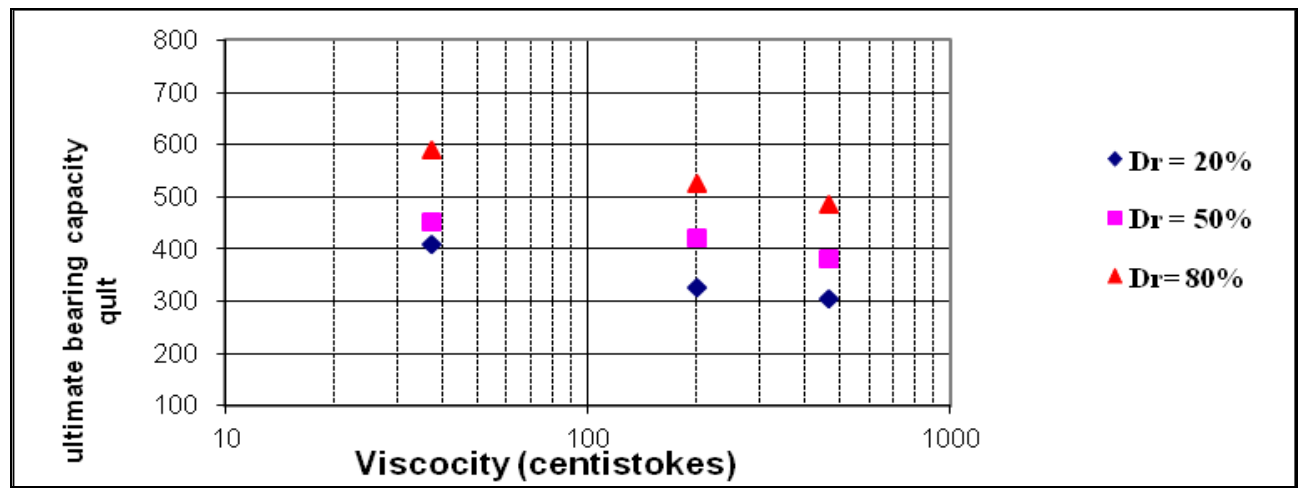

Figure(14): Relationship between oil viscosity and ultimate bearing capacity at $10 \%$ oil content.

\section{REFERENCES}

Ahmed, A. A., Abdelrahman, M.T., Iskander, G.M, Hassan, E.M. (2009), Compressibility of contaminated sand with petroleum oil, International Conference on Soil Mechanics and Geotechnical Engineering, 10(1), $44-49$. 
Beier, N., and Sego, D. (2007). The oil sands tailings research facility. Proceedings of the 60th Canadian Geotechnical Conference and the 8th Joint CGS/IAH-CNC Groundwater Conference, Ottawa, Ontario, Canada, October 21-25, 2, 1423-1430.

David B. (1993). Leakage of underground petrol storage tanks, Australla Journal, 30(3), 117-124.

El-sayed H. M. (2009). Behavior of contaminated soils with petroleum oil, M.Sc. Faculty of Engineering, Ain shams University, Egypt.

Fine, P., Graber, E. R., Yaron, B. (1997). Soil interactions with petroleum hydrocarbons: Abiotic processes. Soil Technology 10(3), 133153.

Rajab M. Abousnina, Allan Manalo, Jim Shiau, Weena Lokuge. (2016). An overview on oil contaminated sand and its engineering applications, Int. J. of Geomate 10(1) (SI. No. 19), 1615-1622.

Shin, E. C., Lee, J.B., and Das, B.M. (1999).Bearing capacity of a model scale footing on crude oil-contaminated sand, Geotechnical and Geological Engineering Journal, 17, 123-132. 


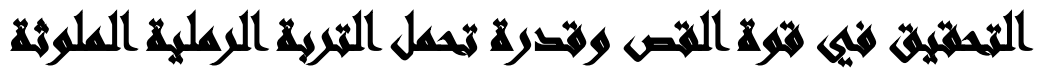

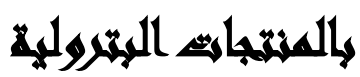

$[r]$

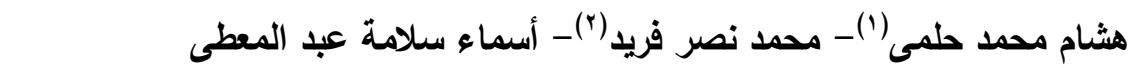

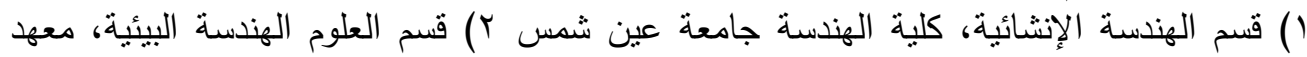
الدراسات البيئية، جامعة عين شمس الإنة الئن

\section{المستخلي}

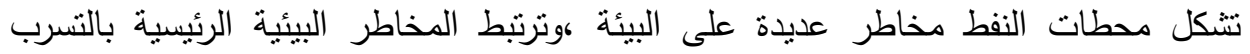

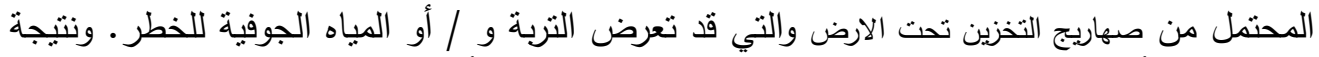

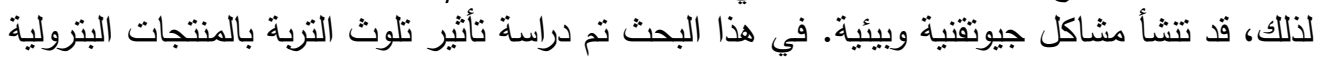

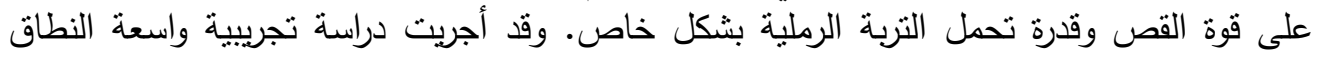

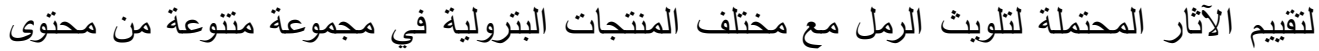

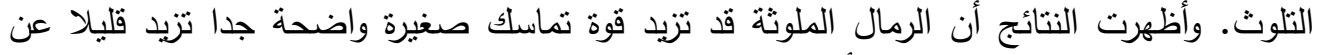

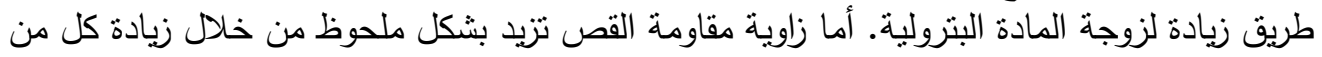

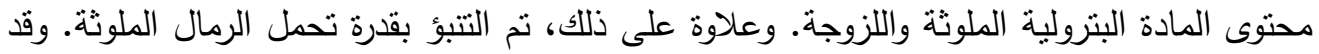
أظهرت نتائج هذا البحث عن انخفاض كبير في قدرة تحمل الأساسات الضحلة على الرمال الملونة 